\title{
The Struggle Over Teacher Training
}

\author{
Alan Barcan
}

$\mathrm{O}$ ver the last seven years strenuous efforts - only partially successful have been made to reform teacher training in Australia. The two main initiators of reform have been the Commonwealth and New South Wales governments. But their efforts between 1989 and 1991 to change the structure and content of teacher training lost momentum in the face of resistance from several interest groups.

Reform was attempted for two reasons. First, the quality of teacher training deteriorated considerably following the replacement of teachers' colleges by teacher preparation in universities and colleges of advanced education (CAEs) in the early 1970s. This brought a more theoretical and ideological and less practical character to teacher preparation. Starting about 1978, attempts were made to restore the quality of teacher training, without avail. Second, in the late 1980 s politicians and their advisers became convinced that students in Australian schools required a more strongly vocational curriculum, as well as higher standards of achievement in the skills. Improvement in schooling required improvement in teacher training.

A struggle ensued between the politicians (tempted by the idea of transferring most teacher training into the schools) and the teacher educators (the university professionals) many of whom feared the loss of their jobs. Soon the educational bureaucracy joined in, attracted by new opportunities for research and reportwriting associated with the search for less radical alternatives. In particular, the identification of teaching competencies opened up tremendous possibilities for research. But just when the 'professionals' could congratulate themselves on diverting the radical proposals for reform into more moderate schemes, they met a new problem. An apparent decline in the demand for teachers led to a fall in the number of teacher educators and of students enrolling in education. Lecturers in teacher training face heavier teaching loads, less time for educational theory and pressures for a strong practical emphasis.

\section{The Deterioration of Teacher Training}

From the early 20th century until the late 1960s teacher training was conducted mainly in small teachers' colleges, controlled by State Departments of Education. The colleges trained primary teachers in two-year courses. Secondary teachers obtained a university degree and then completed a one-year Diploma in Education course given at a college. The colleges had close contact with the schools and de- 
vised their courses to suit the local school system. The lecturers were recruited from successful teachers in state schools. The students held Departmental scholarships and in return signed a bond to serve in government schools, usually for three years, wherever required. After the probationary teachers had taught for three years, inspectors, aided by school principals, confirmed that they were of adequate standard.

The constant shortage of teachers from 1941 to 1975 made it hard to set very high entry standards, and some poor-quality candidates were recruited. On the other hand, the shortage until the 1960s of alternative jobs, in a pioneering society, for educated men and women ensured that many entrants into teacher training had fairly high academic qualifications. By and large, this centralised, state-dominated system produced 'fair average quality' teachers.

During the late 1950s and 1960s the proportion of students proceeding to secondary school grew rapidly. But the proportion of graduate teachers in State secondary schools fell. Between 1955 and 1960 the proportion of full-time secondary teachers with degrees fell in NSW State schools from 52.2 per cent to 42.0 per cent; in Victoria from 66.9 to 65.8 per cent; in Queensland from 50.8 to 26.9 per cent (Barcan, 1977:151). To supplement the supply of teachers, the colleges introduced 'junior secondary' courses. These were 'concurrent' rather than 'end-on' training courses; students studied the academic subjects they would later teach while simultaneously taking method subjects, attending demonstration lessons and engaging in practice teaching.

Between 1967 and 1974 the teachers' college system was dismantled. Teacher training was transferred from small specialised State teachers' colleges to the newlyestablished, large, autonomous, multipurpose, CAEs. The courses were lengthened to three years. The curriculum expanded; more time was found for educational theory. The universities began to offer their own training courses, mainly for secondary teaching. Both the universities and the CAEs were farther removed than the old teachers' colleges from the culture of the schools. Their lecturers often had little teaching experience.

This new system was established for political and financial reasons rather than educational ones. The new CAEs in country regions were short of students; they needed to take over teacher preparation to survive. State governments would save money by transferring teacher training to the Commonwealth-funded CAEs.

Teaching in secondary schools was becoming more difficult and less attractive. Two changes in the mid-1960s exacerbated this trend. The minimum school leaving age was raised from 14 to 15 in 1963/64 (NSW and Tasmania already had a higher minimum leaving age). And many States abolished the external Intermediate Certificate examination, usually taken at age 15 , partly because many of the candidates were now unsuited to an academic examination, partly to save money, and partly because in a time of full employment adolescents could get jobs without an examination certificate. But the effect was to reduce standards. Increasing discipline problems further reduced the attractiveness of teaching as a career. 


\section{The Arrival of Neo-Progressive Education}

In the late 1960 s a new pedagogy, progressive education, swept through Australian schools. Strictly speaking, this should be called 'neo-progressive' education, for it was a new version of earlier 'progressive' principles about a child-centred curriculum, activity methods of learning and integrated subjects. To this the neoprogressives added 'open education'. This could be physically open - several classes in a large open space, with team teaching - but also intellectually open, in the sense that teachers should not impose their ideas on students. This latter view, asserting that all beliefs were equally valid, was an expression of cultural and moral relativism.

Another progressive reform making teaching more difficult was a new approach to the curriculum. Around 1971, departments of education ceased to issue syllabuses; teachers were expected to devise their own 'school-based' curricula. Inspection was almost abolished. The resignation rate rose rapidly, particularly in secondary schools. In New South Wales, for instance, the resignation rate in state secondary schools rose from 9.6 per cent in 1965/66 to 13 per cent in 1968/69 (Barcan, 1977:154). Teachers' salaries fell relative to other vocations. More money was found for education, but it was spent on buildings, on equipment and materials, on expanding the non-teaching ancillary staff and on increasing the number of teachers. More teachers meant smaller classes, but this was not sufficient to restore the attraction and prestige of teaching. Moreover, by the late 1960s a much wider range of jobs was available for those who once would have had few alternatives to teaching.

Many lecturers in 'teacher preparation' courses in CAEs and universities welcomed the new progressive pedagogy. But the progressives lacked a strong theoretical base. It was the neo-Marxists, the radical educationists, who had the theoretical strength. Unlike classical Marxism, which regarded education as part of the 'superstructure' of society, neo-Marxism held that the schools were vital agents for changing society; the 'traditional' curriculum was a 'social construct' reflecting class interests and possessing no intrinsic validity; working-class 'kids' should not be forced to acquire 'middle-class' knowledge. These ideas gained theoretical expression and respectability through the 'new sociology of education' and its offspring, the sociology of knowledge. These new ideologies were expounded in many teacher-preparation courses by lecturers who compensated for their limited knowledge of or interest in school realities by developing an enthusiastic appetite for social theory.'

Many schools soon abandoned the more extravagant experiments, but in the training institutions many lecturers clung to progressive and/or radical ideologies. Teacher-preparation courses often served to alienate trainee teachers from their future profession.

' For the new sociology of education and teacher preparation, see Barcan (1993:193-203.) 
The problems facing future primary and secondary teachers differed. In secondary schools, particularly senior secondary schools, academic subjects remained strong and future teachers needed a firm foundation in subject content and in related teaching skills. But in primary schools, and to some extent in the junior years of secondary schools, the absence of external examinations, syllabuses or inspection encouraged a shift of emphasis from content to process. It was argued that 'learning how to learn' was more important than learning specific content. Inappropriate methods of teaching reading and writing in infant classes, justified by the findings of 'educational research', weakened standards in later primary and secondary grades.

The shortage of teachers meant that no matter how inadequate their preparation, the products of university and CAE teacher-preparation courses could get jobs. This situation started to change in 1976 when, for the first time since 1940, a surplus of teachers appeared.

Concern at the quality of teacher preparation led to the appointment of six committees of enquiry between 1977 and 1981: one in each of the mainland States, and a Commonwealth enquiry. Not much eventuated, if only because, as Professor J. J. Auchmuty of the Commonwealth Committee discovered, 'There is no consensus in this country about education, either between parents and institutions or amongst institutions' (The Australian, 19 November 1980). In any case, the autonomy of the universities and the CAEs made reform difficult. The main outcome was attention to in-service education - improving teachers after they had completed their initial training. Little benefit was apparent.

\section{Commonwealth Reform Initiatives}

What was wrong with teacher education? The short answer is suggested by the changing nomenclature. Until the 1960 s the term 'teacher training' was widely used to describe pre-service courses for future teachers. Then vaguer, more ambitious terms, such as 'teacher education' and 'teacher preparation', became popular. When John Dawkins, Commonwealth Minister for Employment, Education and Training, presented his statement Strengthening Australia's Schools in May 1988, he revived the older, more practical, term: 'We must examine means of improving the initial and ongoing training of teachers to meet the demands of a changing educational, economic and social environment' (Dawkins, 1988:8). But the problem was not simply one of adapting teacher training to a changing environment. It was also one of reversing the deterioration in the quality of teacher training over the preceding two decades. This would necessitate strengthening the training element in teacher preparation and reducing the place of an educational theory that often carried messages quite antagonistic to the preparation of effective teachers.

John Dawkins saw the improved education and training of Australian adolescents, particularly in State schools, as essential for the reshaping of the economy to make it more effective both at home and in a competitive world. The quality of teachers is an important element in the improvement of education; hence the need to attend to teacher training. In addition, reform might reduce the cost of teacher training. 
The Commonwealth bureaucracy generated a variety of reports and discussion papers. Dr Graeme Speedy prepared a Discipline Review of Teacher Education in Mathematics and Science for the Department of Employment, Education and Training (DEET) in October 1989. (Auchmuty had noted in 1980 that many primary teachers lacked competence in maths.) A month later came a Schools Council report for the National Board of Employment, Education and Training (NBEET), Teacher Quality: An Issues Paper. The Australian Education Council (AEC), consisting of the nine ministers for education of the Commonwealth, States and Territories, commissioned a Working Party whose report, Teacher Education in Australia, appeared in July 1990. This was the key document. The NBEET analysed the three 1989-90 reports in The Shape of Teacher Education: Some Proposals (December 1990). In the same month a Schools Council paper, Australia's Teachers: An Agenda for the Next Decade, included a chapter on the training of teachers.

Then carne a pause. The universities and CAEs were engrossed in the restructuring required by Dawkins's Unified National System. Where CAFs merged with universities, the faculties, departments and schools of education also gradually merged.

These documents identified as one major weakness the limited practical experience of many teacher educators: 80 per cent had not taught in schools since the 1970s. Another weakness was the insufficient time allocated to practical aspects, notably practice teaching. A third problem was the uncertain quality of students entering teacher training courses and the shortage of applicants in some teaching subjects. A discussion paper from DEET, Teacher Education, published in August 1992, commented on 'the obsolescent teaching experience of staff in education faculties'. More than 50 per cent had not taught in schools in the previous 20 years (Deer et al., 1993:86-7). A report by the House of Representatives Standing Committee on Employment, Education and Training (The Literacy Challenge, December 1992) complained of the neglect in many teacher preparation courses of language and literature, early childhood education and special education.

The reforms suggested in the 1989-90 documents included: internship or apprenticeship (transferring a major share of teacher training to master teachers in the schools); lengthening all courses to four years (despite some objections on the grounds of cost); sending education lecturers back to the schools at regular intervals to refresh their knowledge of teaching; seconding outstanding teachers to education faculties; and revising the curriculum of training courses (implying less attention to theory, new courses and more attention to basic problems, such as methods of teaching reading and special education).

The structural solution proposed by the AEC's working party report, Teacher Education in Australia, was a three-year program leading to a B.A. (Teaching) or B.Sc. (Teaching). Graduates who obtained a half-time appointment in a school as an 'associate teacher' would then take a part-time two-year course, involving some academic study and some school induction work. This was an attempt to solve the 
tension between the teacher educators (who feared the loss of their university jobs) and the politicians (who favoured a more practical teacher training).

\section{New South Wales Initiatives}

New South Wales had been extremely energetic and radical in school reform. But the controversies this stirred up distracted the attention of Dr Terry Metherell, the Liberal Minister for Education, from teacher training. In any case, he had to await the completion of John Dawkins's restructuring of higher education. Little had been done about teacher training when Dr Metherell resigned in July 1990.

His successor, Virginia Chadwick, produced a discussion paper in September 1990, Teacher Education: Directions and Strategies. It was surprisingly moderate - for reasons that will emerge below. The discussion paper referred to Britain's Council for the Accreditation of Teacher Education, which could approve initial teacher-training courses and had recently been reconstituted to increase its bite. But its section on 'Alternative Pathways to Teaching' simply mentioned, without elaboration, the radical concept of 'licensed' and 'articled' teachers and did not mention current British initiatives to encourage an apprentice-type, on-the-job, training. It also mentioned American attempts to identify specific competencies for future teachers and various American alternative certification programs, 'outside the mainstream'. But it failed to elaborate on the alternative certification approach. It warned that whereas teacher shortages might necessitate more flexible pathways, the use of teachers without formal qualifications might be seen as 'unduly diminishing the relative value of pedagogical and educational knowledge and skills' (Chadwick, 1990:42-3).

Mrs Chadwick took up a British idea when she suggested in November 1991 that education lecturers would be 'encouraged' to return to the classroom for one term every five years (Totaro, 1991). But the Teacher Education Action Plan that she issued in February 1992 took a moderate line. It resulted, in May 1992, in a Ministerial Advisory Council on Teacher Education and the Quality of Teaching.

In June 1992 the NSW Director-General of School Education, Dr Ken Boston, momentarily revived the radical agenda. He warned that 'tinkering at the edges of the teacher training system will no longer work'. Adopting recent English and American ideas, he suggested that up to 80 per cent of training (i.e. four days out of five) should be in schools; schools should have an input into teacher training policies; universities should attempt to recruit more mature-age graduates into teacher training; and educational theory was, perhaps, better placed in in-service rather than in pre-service training (Totaro, 1992).

But it was too late. The teacher professionals had rallied their forces.

\section{Teacher Educators Fight Back}

When the reform of teacher training was first proposed the teacher educators were mute. They had fallen silent as public discontent over the outcome of two decades of progressive and radical nostrums found forceful expression in a drift of enrol- 
ments from state to non-state schools. By the mid-1980s ideological theorising had diminished. Neo-Marxism and the new sociology of education suffered an eclipse. In education courses systematic educational theory evaporated as students tumed to courses that promised practical utility. Like the rest of the academic world, teacher educators were silent when John Dawkins's Unified National System turned higher education upside down.

But two forces fuelled a counter-offensive by the teacher educators. One was their hostility to John Dawkins's new instrumentalism, whose emphasis on practical, vocational, education threatened to dominate teacher preparation. A second was their fear that they would lose their jobs if the preparation of teachers were transferred largely to the schools. We will consider these forces in turn.

Despite the collapse of neo-Marxism, radical theories survived in teacher education programs. The new emphasis on practicality meant that they were often introduced surreptitiously, for instance in curriculum studies courses. Some sociology of education courses survived in their own right. A degenerate version of Marxism persisted under the name of 'critical theory'. Concern with power and with local groups rather than grand theory became a feature of the 'postmodern' outlook. Feminism was another radical theory, incorporating elements of both critical theory and postmodernism. Some educational theorists borrowed ideas from literary criticism. Deprived of their policy-making roles and diminished in prestige, some academics now found compensation in elaborating complex theories. But the less intellectual contented themselves with applying simplified sociological concepts to educational issues, with much emphasis on 'social justice'.

The hostility of critical theorists to instrumentalism is evident in an attack by three Queensland academics in The Australian Teacher of August 1990 on the AEC report, Teacher Education in Australiz. They argued that the report did not understand the needs of the profession, did not realise the importance of student teachers 'reflecting on how children learn', provided an 'unthinking resolution' of practical problems and did not appreciate the industrial implications of creating associate teachers. The report, they said, was part of a drive to corporate federalism based on neo-corporatism, economic rationalism, corporate managerialism and human capital theory (Lingard et al., 1990). Responding to this, Robert Bluer, a counsellor of the NBEET and a member of the AEC working party, said that these educators were not disinterested observers but partisan participants with a barrow to push. Teacher educators, he said, were alarmed because they were being asked to improve their performance. 'Employing authorities must be given a greater role and influence in the training of its (sic) future workforce' (Bluer, 1990).

The teacher educators were no small pressure group. They had an empire to defend. The number of teacher educators grew from 2,063 in 1987 (10.8 per cent of the total of 19,137 academics) to 2,576 in 1991 (11.3 per cent of the 22,867 academics). At stake, too, was a significant proportion of university enrolments. In 1991 education accounted for $74,300-22.8$ per cent - of the 325,500 'effective full-time' enrolments. The statistics (taken from DEET's 1993 National Report on Australia's Higher Education Sector) must be treated cautiously, and not all educa- 
tion lecturers or education students were directly engaged in teacher preparation; yet they all derived their sustenance ultimately from this activity. But the fear of being superseded was real enough. The Australian Teacher Education Association (ATEA) held its mid-1992 conference in an atmosphere of gloom. 'We may all become redundant', said a Queensland critical theorist.

However, the professional educationists rallied their forces. In New South Wales they formed the NSW Teacher Education Council in 1990, in time to have some input into the September 1990 Discussion Paper. This helps explain its subdued approach to reform. The subsequent February 1992 Teacher Education Action Plan, published by the NSW Office of Education and Youth Affairs, reassured the teacher educators. It asserted that the emphasis in the Discussion Paper had been 'on strengthening and enriching existing models of pre-service education rather than on promoting structural changes'. The Action Plan likewise sought to 'strengthen existing pre-service courses'. It emphasised the importance for teacher education students of a mastery of subject matter. They also needed a mastery of 'essential and broad professional teaching competencies'. A new advisory council on teacher education and the quality of the teaching profession would direct its attention to these competencies. The idea of 'alternative pathways into teaching' was seen as related only to 'areas of shortfall' and was deprecated as generating concern 'that standards would be lowered'.

The Ministerial Advisory Council on Teacher Education and the Quality of Teaching set up in New South Wales in May 1992 had 36 members and was chaired by the Director-General of School Education. It represented the major pressure groups: the vice-chancellors, representatives of the Department, the Ministry, the Board of Studies, the Catholic Education Commission, the Association of Independent Schools, the Director of TAFE, the two teachers' unions, the Parents and Citizens Association, teachers from government and non-government schools and nine nominees of the Minister. The Advisory Council reoriented the reform movement. The topics for its first five monthly meetings were: Beginning teacher competencies; Guidelines for teacher educators to have recent school experience; Alternative pathways into the NSW teaching service; Current programs for preparing teachers; and Strategies for ensuring commitment to improving standards (Deer et al., 1993:85).

At the national level, too, the resistance of teacher educators was strengthened when an Australian Council of Deans of Education was established in January 1991. When the DEET issued its discussion paper, Teacher Education, in September 1992 it received 700 responses, the majority hostile. The Commonwealth, with a new Minister for Education (Kim Beazley) and an election in the offing, placated the professionals. The Ministerial Statement Teaching Counts (15 January 1993) reassured educationists in carefully chosen words that the government 'values the role of universities in teacher education, not least because of their responsibility for keeping teaching practice at the forefront of knowledge'. It endorsed the proposal for a National Teaching Council. It told teacher educators that the government 'would not support an apprenticeship model', but that it supported ' a competency- 
based approach' in teacher education. To help 'Education Faculty Renewal' it would fund the early retirement of teacher education staff.

\section{Control through Accreditation and Competencies}

So the educational professionals (academics and bureaucrats) seemed to have won. After five years of reports and discussion papers the drive for reform had been dissipated into a variety of administrative committees, schemes for certificates and research projects. An oblique control would be exercised through registration of teachers based on a variety of criteria, including achievement of competencies at the end of teacher training. A National Teaching Council of 40 elected teachers and 19 others was approved in June 1993 and met in December.

The National Teaching Council had been foreshadowed by the prime minister in an address to the Australian Teachers Union on 15 January 1993. It would accredit new teachers on the basis of their possessing specific competencies, which would include broad skills such as communications, classroom relationships and planning and evaluating student learning. The scheme was supported by the DEET, the Council of Deans and the Australian Teachers Union. The Education Faculties would be prodded with competencies, cajoled with special funding. Teaching Counts promised 'up to' $\$ 130$ million over the next three years to assist teachers to update their skills and for further work on key competencies, including a 'prototype training and development package for teachers/trainers'.

But who would control the Council, and what policies would it implement? Some observers feared that the Council would become an extension of the teacher unions. The education systems were given representation on the Board, but at the December meeting only two of the eight States and Territories, the ACT and South Australia, had taken their places (Australian Parents Council, 1994). Some administrators (such as Dr Tannock, Director of Catholic Education in Western Australia) disliked the idea of a National Teaching Council. Some States, such as Victoria, were hostile, preferring their own accreditation bodies. New South Wales had no system of registration of teachers but could use the Ministerial Advisory Council on Teacher Education and the Quality of Education to influence the training institutions.

The notion of competencies was not new. Its latest reincarnation arose out of a 1990 Commonwealth/State Training Advisory Committee document, A Strategic Framework for the Implementation of a Competency-Based Training System. The idea was given wider currency in the AEC's Young People's Participation in PostCompulsory Education and Training: Report of the Australian Education Review Committee of July 1991 (the Finn Report) which identified six 'key competencies' essential for employment and recommended national standards in assessing and reporting key competencies. The adoption of competencies had several attractions for teacher educators. It avoided that danger of direct prescription of content by an external authority. While competencies might provide some basis for external appraisal, their assessment promised to be very vague. But some teacher educators 
resented even the mild control of competency-based training. Some feared that the pursuit of competencies might reduce attention to content.

On the other hand, the compilation of teacher-education competencies provided a new bandwagon for the educational bureaucracy. The National Project on the Quality of Teaching and Learning, which had generated the idea of a National Teaching Council, commissioned Professors Ken Eltis and Cliff Turney of the University of Sydney to devise a statement of 'general competencies' for beginning teachers. Conceivably, these could be used to guide teacher training institutions. Sceptical teacher educators could accept 'competency-based training' as a harmless if pointless alternative to closer scrutiny. Eltis and Turney's report (1993) identified 22 'generic competencies for beginning teachers', such as 'demonstrating and enhancing curriculum expertise', 'planning for leaming' and 'developing and integrating theoretical understandings' - worthy but evasive concepts.

\section{A New Threat: Reduced Demand for Teacher Training}

The professionals had defused the threat that they might lose their jobs through school-based training. But now a new threat appeared: redundancy because of falling demand. A DEET discussion paper, Teacher Education, published in August 1992, argued that there was an oversupply of teacher education graduates, that fewer than 50 per cent of graduates would find work as teachers and that this would be the case till at least the middle of the decade.

The argument that falling demand for teachers justified a reduction in the number of teacher educators alarmed both teacher unions (seeking lighter class loads, i.e. more teachers) and the professional organisations of academic educationists (seeking to maintain jobs). A battle of statistics developed. 'Education deans are beginning a push to win back resources for their faculties', wrote Jane Richardson, editor of the Higher Education section of The Australian on 20 July 1994. A consultant hired by the Australian Council of Deans of Education had carried out a survey that predicted 'a substantial and widening gap between supply and demand for teachers to 2001'.

Theoretically, any shortage could still be met in the schools themselves, by a system of internship or by employing mature adults with little or no teacher training ('alternative pathways'). But during 1993 both policies were discarded. Another solution would be for the academic professionals to take heavier teaching loads. Indeed, this had happened in the new universities as the gap between the teaching loads of the old universities and the CAEs shrank. Whatever the solution, a reduction in the number of teacher educators would, presumably, encourage reduced attention to educational theory and a concentration on practical training.

To assist 'Faculty Renewal' Teaching Counts had promised to fund the early retirement of education staff. Early retirement offered two benefits. First, the new universities had to reduce costs and the easiest way was by reducing the number of lecturers. The easiest faculties in which to reduce staff were arts and education. Second, it made it possible to recruit education lecturers with recent experience in 
schools. It might permit employment of part-time staff (cheaper than full-time), who could combine teaching and lecturing (often a desirable arrangement.)

Generous early retirement schemes started at the end of 1993. But policies varied from institution to institution. In Victoria, where the demand for teachers slumped when the new Liberal government imposed cut-backs on schools, the University of Melbourne declared 59 members of the Institute of Education 'surplus' (average age 46, average years of tenure 20) (The Australian, 20 July 1994). On the other hand, Deakin University decided to dispense with 23 contract staff in education. Staff levels in the education faculty were expected to more than halve in the two years 1993-94 (Campus Review, 25 November 1993). In May 1994 the University of Newcastle was reported to be planning to reduce student numbers in the education faculty by one-third over the next five years, redistributing some 800 fulltime student places among the other faculties (The Newcastle Herald, 13 May 1994).

Whatever the reason, student numbers were falling. The number of higher education students enrolled in education peaked at 78,982 in 1991, and by 1993 had fallen to 75,613. Yet this was still more than in 1990 (Higher Education Council, 1994:42).

\section{The Current Situation}

The annual conferences of the ATEA provide a barometer of the changing climate. The 1992 conference at Ballina, New South Wales, was marked by considerable gloom (Barcan, 1992). The 1993 Fremantle conference was characterised by 'considerably more optimism than one might have expected' (Ryan, 1993:2). The program for the 1994 conference, 'Empowering the Professionals', showed that, although threats persisted, the teacher educators had hopes of a recovery.

In March 1994 the ABC Radio National's Education Report devoted two sessions to a discussion of the current state and future directions of teacher education. Two academics from the University of Melbourne defended the redesign of their university's teacher education program as a chance to change the community's view of the standards of teachers. Some speakers welcomed competency-based training. Bill Lowden of Edith Cowen University warned that competencies might be too narrow; they should be 'somewhere between a 1000 tiny parts and something so mysterious you can't write about it'. Other speakers seemed enveloped in an unreal world of theory, advocating critical reflection, a conflation of critical theory and reflective teaching (a pretentious name for an obvious activity: teachers reflecting on what they were doing). A lecturer from the Queensland University of Technology told how she used stories to develop ideas about what it means to teach and 'how it is we understand about teaching'. Her teacher-training work focused on the changing metaphors teachers use as they increase their experience. The speakers were uncomfortable when asked about criticisms that they neglected the particularities of teaching. Many of them accepted this, but identified obstacles to implementing reform. Ken Eltis and Bob Meyeen, explaining the provocative title of their recent paper 'Teacher educators as a pod of middle-aged beached whales', said that 
teacher educators had become good at protecting their territory, but needed to be more realistic and honest. They were hesitant about change, which often meant a loss of jobs. But they argued that many lecturers did go into schools and had contact with school reality. One academic who supported change, Lawrence Ingvarson, wanted a national agency to accredit courses; academics had not been sufficiently accountable (Perry, 1994).

Nonetheless, a considerable swing towards more emphasis on in-school preparation was occurring. At the end of 1992 the Dean of the Institute of Education at the University of Melbourne announced that the four-year B.Ed. degree would be phased out in favour of a two-year postgraduate Bachelor of Teaching degree, including a year's on-the-job internship.

\section{Does it Really Matter?}

Does the form of teacher training really matter? For more than 50 years beginning teachers arriving at their first school have been greeted by the old hands with the advice to forget what they had been told at college. Now they were in the real world. And it is true that teachers really learn to teach in their first three years in schools.

But it is also true that future teachers do pick up attitudes in training courses: dedication to the cause of teaching, or scepticism about the purposes or value of teaching. They pick up some basic survival techniques during their supervised practice teaching: the need to have work ready when a lesson begins, the importance of varying procedures in the course of a 30 - or 40 -minute period, the mannerisms of a professional teacher. Some basic skills can be imparted in prior training: in English, the importance of phonics for teaching reading and the value of grammar for clear expression, for correction of written work and as an aid in learning foreign languages.

Possible defects in university preparation of teachers include lack of commitment to teaching on the part of some lecturers, excessive attention to progressive or radical theory, neglect of practical teaching skills, and isolation from schools and classroom teachers. But would internship be much better? Teachers can be cynical, use bad methods, or provide a faulty model, such as laziness. The quality of internship would rest heavily on the quality of the master-teacher. Apart from the need for a careful choice of master-teachers, the neophyte must be inducted by graded stages into the difficult art and skill of teaching.

Perhaps the system of teacher training is less important than recruitment of the right sort of teacher. Perhaps there should be better selection, using academic, psychological, and moral criteria. Perhaps better teaching requires better guidance and supervision of teachers inside the school.

\section{Options for Change}

The politicians seeking in the late 1980 s to reform teacher training had confronted powerful vested interests. Once the initial enthusiasts - John Dawkins in Canberra 
and Terry Metherell in New South Wales - disappeared, once the initial momentum slowed, the educational-bureaucratic complex was able to block serious reform. In school reform Metherell, and in higher education reform Dawkins, both adopted policies of 'crash through or crash'. Their reforms were introduced speedily and with limited discussion. The educational-bureaucratic nexus had little time to rally in opposition. But in the reform of teacher training both Dawkins and Metherell adopted a 'softly softly' approach. This reasonable, gradualist approach gave the vested interests time to organise and fight back.

Because of the obduracy of many teacher educators, educational bureaucrats and the professional and union leaders, vast sums of money were wasted on devising solutions that were at best unhelpful. They are unlikely to improve the quality of teacher training and will strengthen rather than reduce the vast educationalbureaucratic complex.

Some vocations, such as journalism and nursing, are better taught on the job and have suffered from being shifted in recent years into institutions of higher education. Transferring the bulk of teacher education to the schools would reduce or eliminate radical or progressive waffle and give teacher training a strongly practical character. It could save money - which should appeal to politicians and public servants. But it would threaten the very existence of old, entrenched, teacher educators. School-based training would have problems, of course. It would be difficult to ensure an adequate supply of competent 'master-teachers'. Too early an exposure to the stiff challenges of many schools might deter some candidates. The AEC's three-year plus two-year internship compromise is a reasonable one, but might be expensive. Another proposal, the extension of three-year courses into four years, is of dubious value, though if the three years were devoted to advancing the general education of the trainees and the fourth year to in-school experience, it could be beneficial.

Perhaps improvement in the quality of teaching is better promoted at the point of entry into the profession, by the school as an employing agency. The selection of teaching staff by merit (by open advertisement arranged by each school council) might stimulate quality. Of course, no scheme is proof against abuse. Schools in less salubrious parts of Australia might receive applications from the more poorly qualified - though salary and other adjustments could correct the balance. And there is always the danger that assessment of teaching quality would degenerate into assessment of elegant but specious application portfolios.

If internship cannot be achieved, one alternative could be for each State to establish one model training school, to set standards for the other teacher-training institutions. This would revive some of the better features of the former teachers' colleges. It could offer a postgraduate two-year course, using demonstration lessons and providing considerable practice teaching. It would be small. The instructors would be recruited from the teaching service and would emphasise practice, not theory. Special arrangements to recruit mature adults to be trained in the schools should also be considered. 
For the moment, however, we are promised a tortuous form of indirect control through a National Teaching Council, using the dubious concept of competencies. The restoration of accountability in teacher training would be advanced not by a national body issuing vague descriptions of necessary teaching skills but rather by regional bodies that do something to restore the earlier system of examination and inspection of beginning teachers. But instruments of control can be given new orientations. What if a National Teaching Council were, in a few years, to require that all entrants to the teaching service should have spent 80 per cent of their professional preparation in the schools?

\section{References}

Australian Parents Council (1994), 'Australian Teaching Council Meets', APC Review 20(1): 7.

Barcan, A. (1977), 'The Decline of Teaching', in A. Spaull (ed.), Australian Teachers: From Colonial Schoolmasters to Militant Professionals, Macmillan, Melbourne.

- (1992), 'Teacher Educators in Search of a Future', Education Monitor 3(3): 12-13.

- (1993), Sociological Theory and Educational Reality: Education and Society in Australia since 1949, University of New SouthWales Press, Sydney.

Bluer, R. (1990), 'Teacher Education: Getting it Right', The Australian Teacher, No. 27, November: $23-4$.

Chadwick, V. (1990), Teacher Education: Directions and Strategies, NSW Ministry of Education, Youth and Women's Affairs, Sydney.

Dawkins, J. (1988), Strengthening Australia's Schools, reprinted in Curriculum Australia, No. 7, October: 8.

Deer, C. et al. (1993),'Politics of Teacher Education in New South Wales, Australia', Education Research and Perspectives 20(1): 86-7.

Eltis, K. \& Turney, C. (1993), 'Defining generic competencies for beginning teachers', Research Project 2, Unicom 19(3): 33 .

Higher Education Council (1994), Eighth Report to the National Board of Employment, Education and Training, AGPS, Canberra.

Lingard, R. et al (1990), 'Teacher Education: Developments and Context', The Australian Teacher, No. 26, August: 20-3.

Perry, C. (1994), 'Teacher Education: The Talk of the Town', ATEA News/etter 17(4): 4-6.

Ryan, M. (1993), 'Challenges we Face in Teacher Education', ATEA Newsletter 16(3): 2.

Totaro, P. (1991), 'Teachers' teachers go back to school', The Sydney Moming Herald, 7 November.

(1992), 'Class training plan for teachers', The Sydney Morning Herald, 11 June. 